\title{
DIETARY FIBRES AND BREAD: ATTITUDES, BELIEFS AND KNOWLEDGE AMONG YOUNG POPULATION
}

\author{
Zita I. Šereš ${ }^{1}$, Dragana M. Šoronja Simović ${ }^{1}$, Maja J. Grujičić ${ }^{2}$, Ferenc E. Kiš ${ }^{3}$, Marijana Z. Djordjevićs ${ }^{1}$, \\ Olivera D. Šimurina ${ }^{4}$, Žana V. Šaranović $^{5}$, Nikola R. Maravić ${ }^{1}$ \\ ${ }^{1}$ University of Novi Sad, Faculty of Technology, Department of Carbohydrate Food Engineering, 21000 \\ Novi Sad, Bulevar cara Lazara 1, Serbia \\ ${ }^{2}$ University of Novi Sad, Faculty of Medicine, Department of General Education Subjects, 21000 Novi \\ Sad, Hajduk Veljkova 3, Serbia \\ ${ }^{3}$ University of Novi Sad, Faculty of Technology, Department of Basic Engineering Disciplines, 21000 \\ Novi Sad, Bulevar cara Lazara 1, Serbia \\ ${ }^{4}$ University of Novi Sad, Institute of Food Technology, 21000 Novi Sad, \\ Bulevar cara Lazara 1, Serbia \\ ${ }^{5}$ Economics Institute, 11000 Belgrade, Kralja Milana 16, Serbia
}

${ }^{*}$ Corresponding author: Marijana Djordjević

E-mail address: maridjo@tf.uns.ac.rs

\begin{abstract}
The link between dietary fibres and prevention of non-communicable diseases is well documented in the existing scientific literature. Despite that, most of the population still do not have enough knowledge about fibres and their presence in certain food. This study intended to make an insight in the knowledge of the Serbian young population about dietary fibres and bioactive compounds through a questionnaire survey. A survey was conducted to a sample of 173 individuals, ( $37 \%$ male and $63 \%$ female) randomly selected among students from elementary, high school and university in the Novi Sad municipality. Topics covered by the questionnaire included knowledge of the term dietary fibre, fibre content in different bread types, the relationship between fibres and health and bioactive compounds sources in food. The results for each of the particular topics addressed varied among studied groups, but generally level of knowledge was related to the education level. The highest overall knowledge about dietary fibres and bioactive compounds was expressed by the university students, although elementary and high school students showed a considerable level of knowledge on the subject. Male participants appeared as more familiar with the questions related to bioactive compounds, while females were more informed on questions regarding dietary fibre. This survey revealed that young population in Serbia is well informed about the contribution of dietary fibre and bioactive compounds in promoting health. However, further expansion of existing knowledge will be beneficial in order to improve general health of the entire community.
\end{abstract}

Keywords: dietary fibres, fibre consumption, questionnaire survey, young population, bread

\section{INTRODUCTION}

In the last decades public interest in healthy diet has increased and thus there has been an increasing demand for healthy foods. An unhealthy diet represents one of the main risk factors for food allergies (Vuksanović et al., 2016) and chronic diseases development (WHO, 2013). Dietrelated diseases affect people across all age groups, social classes and national borders. In addition, young population is the most vulnerable considering important lifestyle changes which cause negative changes in diet. The average student diet is often low in nutrients such as dietary fibres, vitamins, bioactive compounds, low in fruit and vegetable intake, high in sugar, saturated and trans-fat, and sodium intake. Fibre-rich foods include many fruits 
and vegetables, beans, whole grains, and nuts. Ingestion of fibres from different sources is often coupled with the ingestion of other bioactive compounds that would act synergistically in the human body and contribute to the general wellbeing (Macagnan et al., 2016). Children (9-13 years) should eat $26-31 \mathrm{~g}$ of total dietary fibres (TDF) daily, adolescents (14-18 years) 26$38 \mathrm{~g}$ of TDF daily, and adults (19-30 years) 25-38 g of TDF daily (Slavin and Jacobs, 2010). Despite the recommendations the amount of dietary fibres present in young population diet is low, being influenced by changes in living arrangements, costs and financial resources, availability of convenience, preferences for eating outhome, presence of refined and processed types of food on the market, and lack of information on this subject (Tarcea et al., 2016; Bagordo et al., 2013). An adequate dietary fibre intake is associated with a range of important health benefits. The physico-chemical characteristics of dietary fibre such as their solubility and chemical structure constitute the starting point for their physiological effects in human body. A significant number of scientific studies confirm the important role of dietary fibres in the prevention of non-communicable chronic diseases such as obesity, colon, rectal and breast cancers, coronary heart diseases and improved glycemic control among diabetics (Sardinha et al., 2014; Kendall et al., 2010). The role of soluble dietary fibre in the digestive tract is reflected in their ability to associate with bile salts and cholesterol in the small intestine, which decreases their absorption. In the large intestine, soluble dietary fibres promote the formation of short-chain fatty acids, which reduces cholesterol synthesis (dos Santos et al., 2016). The main role of insoluble fibres is to facilitate intestinal transit, and thus reduce the colon exposure to the carcinogens and thereby decrease the probability of cancer occurrence (Elleuch et al., 2011).

Bread is a staple food eaten all over the world and as an integral part of the human diet provides carbohydrates including dietary fibres, protein, minerals, vitamins and many other bioactive compounds. Dietary fibres are concentrated in the kernel bran and germ and therefore wholegrain breads have higher fibre content when compared to white bread. Moreover, it is established that high intake of whole grains and cereal fibre showed significant and consistent protective effects on diseases such as type 2 diabetes, cardiovascular disease and colorectal cancer (Huang et al., 2015). Recently, interest shown by consumers regarding dietary fibre has found the response from the food industry through the development of diverse fibre enriched foods (Guiné et al., 2016).

A number of health complications are starting to increase within the young population implying that increase in fibre intake could be beneficial. However, enrichment of regular diet with fibre rich food still remains a public health challenge. There is no representative data available describing the perceptions of young people about dietary fibres or their levels of knowledge in Serbia. Considering this background, the objective of the present study was to estimate the young population knowledge about dietary fibres and bioactive compounds and their presence in different bread types.

\section{MATERIAL AND METHODS}

\section{Study population}

The present study involved 173 students, including 64 males (37\%) and 109 females (63\%), aged $14-26$ years. Participants were selected by random sampling method among students from elementary schools (31), high schools (45) and university (97) in the Novi Sad municipality. The majority of the surveyed university students attended Faculty of Sciences, Faculty of Technology and Faculty of Technical Sciences. The participation in the survey was voluntary, and the questionnaire was applied by direct interview only after verbal consent was obtained. Prior to filling in the questionnaire, participants were informed of the study's aims as well as that responses would be used only for research purposes and the given information would be treated as confidential.

\section{Survey characteristics}

The self-designed questionnaire included two major sections. The first section co- 
vered demographic data including gender and age along with social and cultural data focused on education level (elementary school, high school or university) and degree course. The second section was focused on testing the attitudes and knowledge towards dietary fibres and bioactive compounds among examined population. In this section, participants completed the questionnaire by marking or ranking the offered responses.

Ethical approval for conducting a survey was provided by the Faculty of Technology Ethical Committee.

\section{Data analysis}

The answers provided by the survey have been collected in a database using Microsoft Excel 2010. Results were processed using the Statistica 13.2 software (StatSoft, Inc., USA.) and expressed in percentages (\%) on the total number of participants based on enrolled school and gender.

\section{RESULTS AND DISCUSSION}

In Table 1 are presented the characterristics of studied young population regarding education level and gender. The majority of the study population consisted of university students (56\%). Considering gender, female participants were more numerous $(63 \%)$. The obtained results regarding participants' knowledge about the dietary fibre term and their content in different bread types are graphically illustrated in Figure 1.

As regard to the dietary fibre term, high school students showed lack of knowledge since $31.58 \%$ were not familiar with this term (Figure 1a). University students prove to be the most informed in the view of dietary fibre term (Figure 1a) which was expected due to the higher education level. Encouraging observation is that $38 \%$ of elementary school students heard or read about dietary fibre implying that in the recent years more information of the corresponding subject was introduced to them. Furthermore, the results showed that females have better knowledge of the dietary fibre term compared to male participants (Figure 1a) since the difference was $7 \%$ in favour of females. In average $24.33 \% \pm 9.24$ participants regarding education level and $26.33 \% \pm 5.8$ participants regarding gender showed knowledge of dietary fibre term. These results are consistent with the previous study of Ljubicic et al. (2017) conducted in Croatia. Still, 30$37 \%$ of all participants, regardless of education level and gender, are not sure what dietary fibre term means indicating that further attention should be referred to the young population education on this subject. When the question addresses the possible relationships between knowledge about dietary fibre and their presence in various bread types, more than $61 \%$ of all participants ranked whole wheat bread as bread with the highest dietary fibre content (Figure 1b). This result indicates either young population awareness that dietary fibres are predominantly located in the bran or increasing influence of market trends. Half white bread is made from partially refined flour (contains bran parts) and thus has higher dietary fibre content compared to white bread.

Nevertheless, neither one of the surveyed participants marked half white bread as first choice revealing lack of knowledge. Similarly to the previous, university students showed the best knowledge on this question too $(74.34 \% \pm 13.14)$, while differrences among genders were minimal $(79.87 \% \pm 2.27)$. When participants were asked to rank breads obtained from different grain flours by dietary fibre content, $47 \%$ of high school students put rye bread in first place followed by $41 \%$ of university students (Figure 2a).

Table 1.

Basic characteristics of studied population

\begin{tabular}{lcccc}
\hline Education & & Males & \multicolumn{2}{c}{ Females } \\
\cline { 2 - 5 } & $\mathbf{n}$ & $\mathbf{0}$ & $\mathbf{n}$ & $\mathbf{\%}$ \\
\hline Elementary school & 19 & 30 & 12 & 11 \\
High school & 12 & 19 & 33 & 30 \\
University & 33 & 51 & 64 & 59 \\
\hline Total & 64 & 37 & 109 & 63 \\
\hline
\end{tabular}




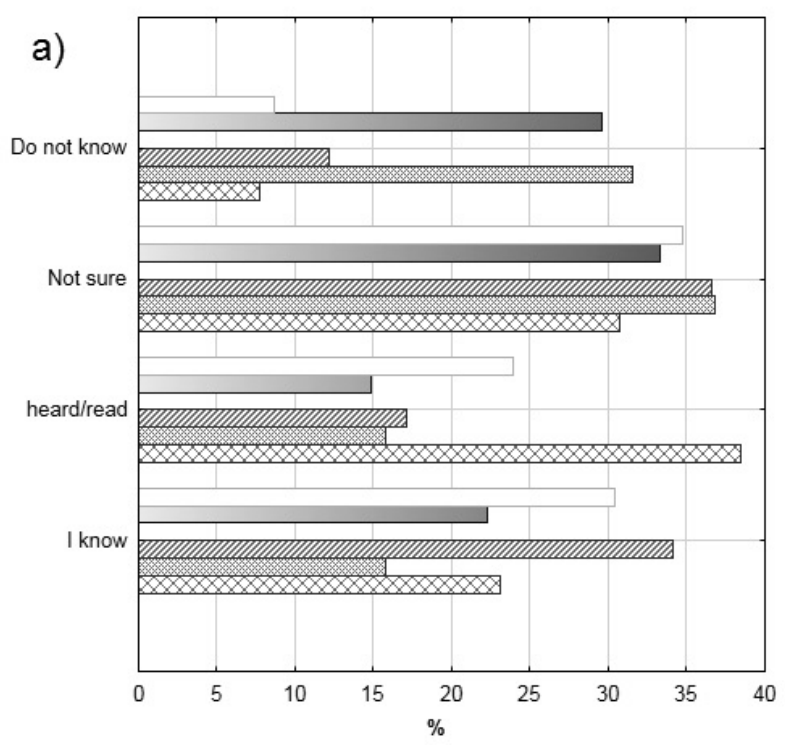

Elementary school

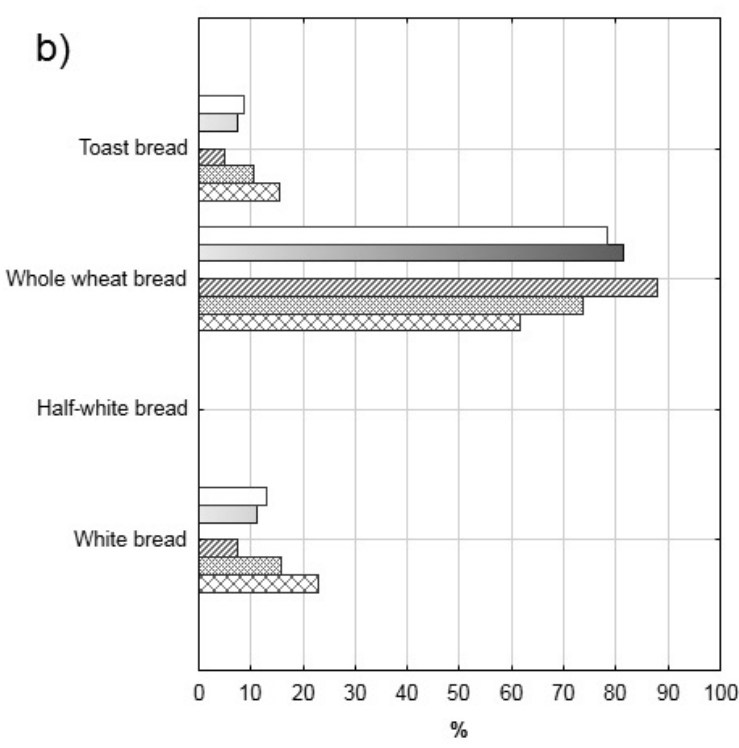

University

Male $\square$ Female

Figure 1. (a) Level of knowledge about dietary fibre term (b) level of knowledge about dietary fibre content in different bread types
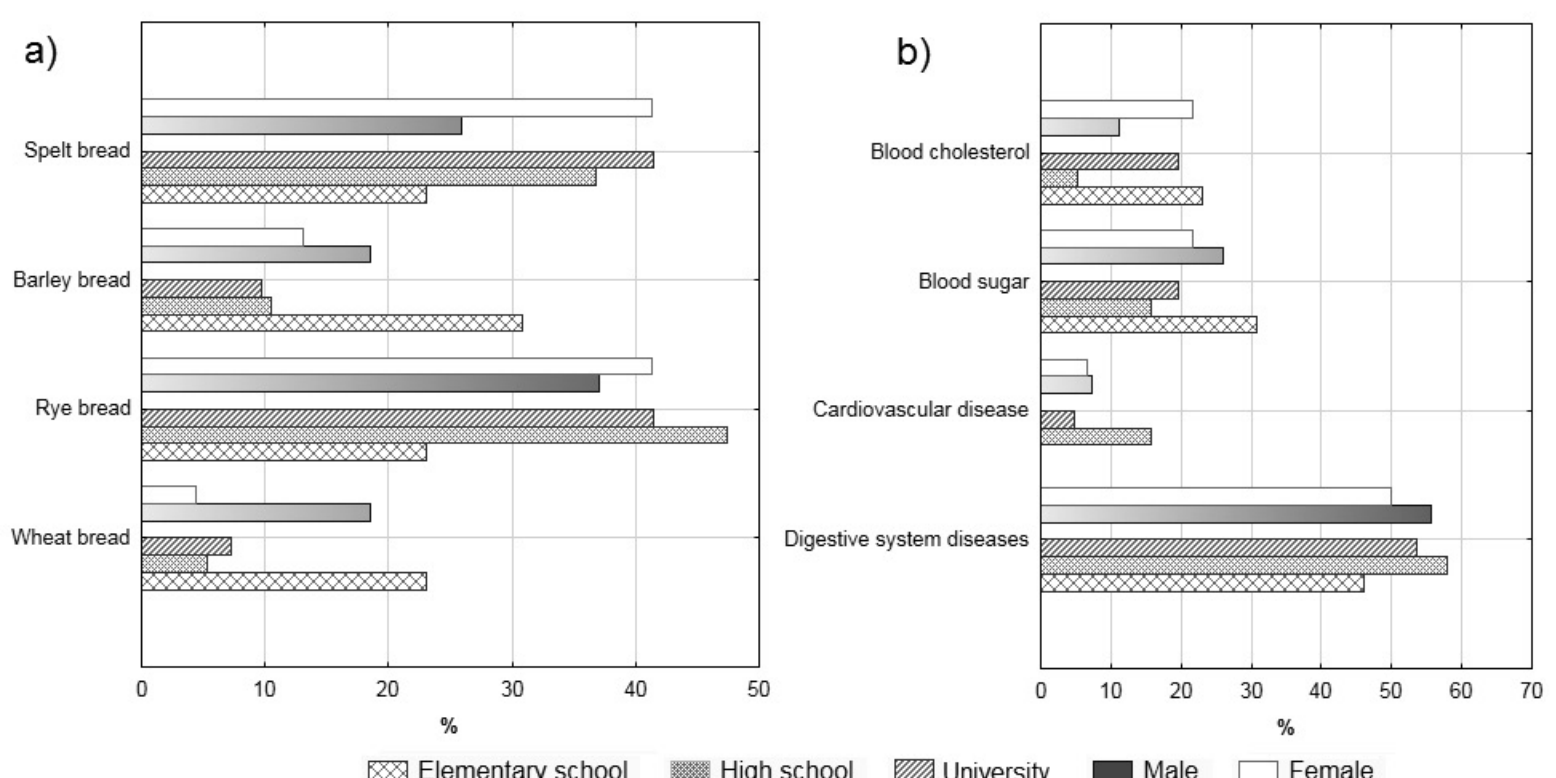

Figure 2. (a) Level of knowledge about dietary fibre content in breads from different grains (b) level of knowledge about dietary fibre role in disease prevention

The highest percentage of elementary school students put barley bread on first place while other bread types were ranked almost evenly (Figure 2a). Considering the ranking of other bread types, it could be assumed that elementary school students do not possess enough knowledge which could enable better understanding of dietary fibre presence in different grains. In recent years, spelt was introduced to the population as a grain healthier than common wheat since is found to have higher content of soluble and insoluble dietary fibres (Bonafaccia et al., 2000). Familiarity with this fact may explain why $23-41 \%$ of participants gave the advantage to spelt bread over barley bread. According to the Food and Drug Administration (FDA), $3 \mathrm{~g}$ of $\beta$-glucan originating from barley and oat per day has a positive nutritional effect (US-FDA, 2001). However, unfavourable position given to barley bread in this survey is more understandable, since this type of information is not so divulged among 
the young population. Considering gender, females seem to be more informed on fibre content in different bread types than males $(39.17 \% \pm 3.01)$. Regardless of education level, approximately half of the participants primarily associated dietary fibre intake with the decreased risk of digestive system diseases $(52.56 \% \pm 5.94)$ (Figure $2 b)$. Elementary school and university students' subsequently ranked blood sugar and blood cholesterol lowering as positive outcomes of dietary fibre intake. Nevertheless, the connection between cardiovascular disease prevention and dietary fibre consumption seems to be unknown to the majority of the survey participants since only $15 \%$ of high school students ranked this response as their first choice. Comparing male and female, large differrences between ranked answers were not observed since the first choice in both cases was dietary fibres linkage with digestive system diseases $(52.77 \% \pm 3.92)$ followed by blood sugar, blood cholesterol and cardiovascular diseases. Considering presented results it could be concluded that surveyed population, in general, is aware of dietary fibre positive influence on mentioned diseases which is in accordance with reported results from similar studies (Szücs et al., 2017; Guiné et al., 2017; Martinho et al., 2013). However,

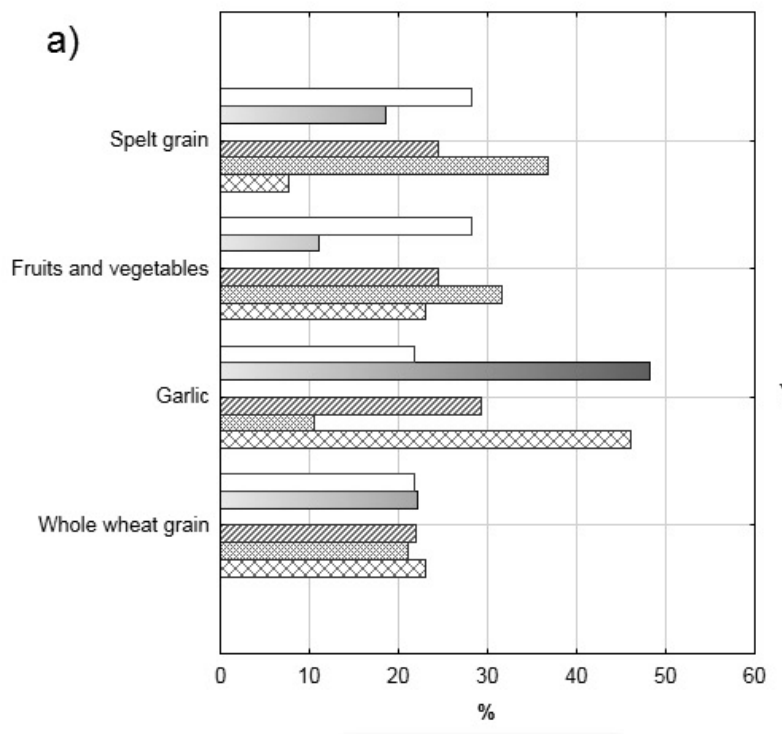

Elementary school High school further expansion of existing knowledge of dietary fibre protective role in cardiovascular and other diseases development needs to be conducted.

On Figure 3 are presented responses obtained for the questions about bioactive compounds sources and participants attitudes towards their application in bread. The responses obtained for the question about the bioactive compounds sources revealed that $46 \%$ of elementary and $29 \%$ of university students affirmed that garlic is rich in bioactive compounds followed by fruits and vegetables, whole wheat grain and spelt grain (Figure 3a). Unlike them, the first choice of high school students was spelt $(37 \%)$, followed by fruits and vegetables, whole wheat grain and garlic. Compared to female, high percentage $(48 \%)$ of male participants marked garlic as first choice implying impact of tradition while only $11 \%$ of males agreed that fruits and vegetables are rich in bioactive compounds (Figure 3a). On the other hand, females gave slight advantage to fruits and vegetables and spelt over garlic and whole wheat grain. Still, in average $28.64 \% \pm 17.82$ participants regarding education level and $34.95 \% \pm 18.67$ participants regarding gender marked garlic as source of bioactive compounds.

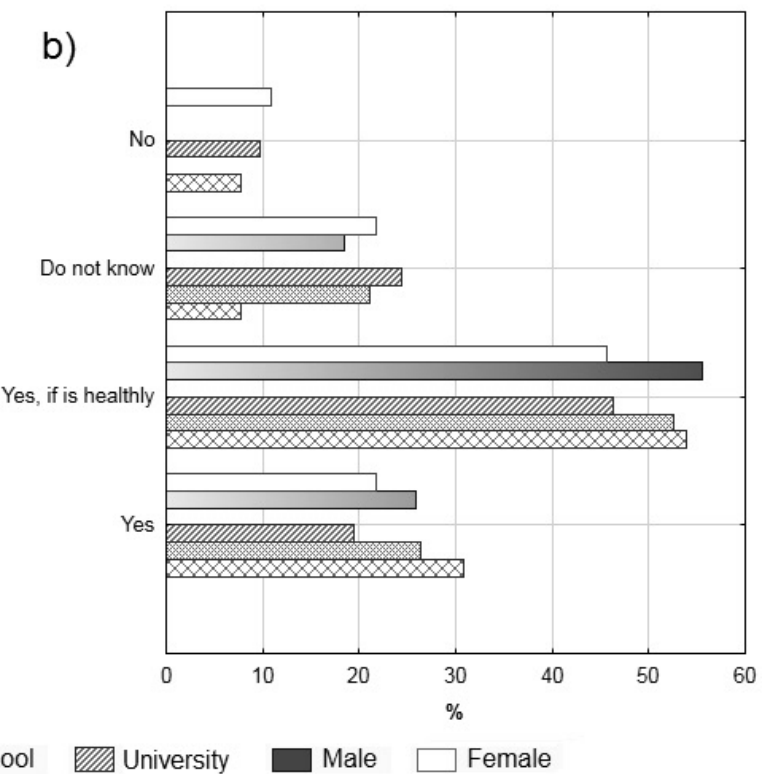

Figure 3. (a) Level of knowledge about bioactive compounds sources (b) attitudes towards bioactive compounds application in bread 
Given the inconsistency observed in the answers of all participants, one can infer that the inquired are familiar but do not possess the desired knowledge about bioactive compounds and their sources. Regarding the question whether bread should be enriched with bioactive compounds more than $46 \%$ of all participants answered affirmatively under the influence of the corresponding statement "if is healthily" $(50.94 \% \pm 4.03)$, but only $20-31 \%$ showed absolute certainty (Figure 3b). Discouraging fact is that $24 \%$ of university and $21 \%$ of high school students did not have an opinion about this, revealing lack of knowledge while $0-10 \%$ showed a negative attitude towards bread enrichment. Participants, regarding gender, in high percentage (46-56\%) also agreed with bread enrichment with bioactive compounds considering statement that is beneficial for health while $22-26 \%$ replied with certainty (Figure 3b). Nevertheless, male participants seem to be more open-minded in terms of bread enrichment with bioactive compounds when compared to females, since no negative answers were obtained.

\section{CONCLUSIONS}

This study allowed comparing education level and gender of young population in relation to the attitudes and knowledge about dietary fibre, their presence in different bread types, relation with disease prevention, and bioactive compound sources. The obtained results showed that the higher education level has great influence on the overall knowledge about dietary fibres and bioactive compounds since university students were the most informed on the subject. Considering gender, females showed a higher level of knowledge regarding questions about dietary fibres, while males were more informed on questions related to bioactive compounds.

Although all participants included in the study showed certain level of knowledge on the subject the inconsistency observed in some answers drive on to conclude that further education of young population should be conducted because only wellinformed population can recognise and consume fibre-rich products and thereby take advantage of the health benefits that fibre can offer.

\section{ACKNOWLEDGEMENTS}

This study is supported by Project of the Provincial Secretariat of Vojvodina for Higher Education and Scientific Research (Project no. 142-451-2637/2017).

\section{REFERENCES}

1. Bagordo, F., Grassi, T., Serio, F., Idolo, A., De Donno, A. (2013). Dietary habits and health among university students living at or away from home in southern Italy. Journal of Food and Nutrition Research, 52, 164-171.

2. Bonafaccia, G., Galli, V., Francisci, R., Mair, V., Skrabanja, V., Kreft, I. (2000). Characteristics of spelt wheat products and nutritional value of spelt wheatbased bread. Food Chemistry, 68, 437-441.

3. dos Santos, P.V.F., Sales, C.H., Vieira, D.A.S., de Mello Fontanelli, M., Marchioni, D M., Fisberg, R.M. (2016). Family income per capita, age, and smoking status are predictors of low fiber intake in residents of São Paulo, Brazil. Nutrition Research, 36, 478 - 487. http://dx.doi.org/10.1016/j.nutres.2015.12.011

4. Elleuch, M., Bedigian, D., Roiseux, O., Besbes, S., Blecker, C., Attia, H. (2011). Dietary fibre and fibrerich by- products of food processing: characterisation, technological functionality and commercial applications: a review. Food Chemistry, 124, 411-421. https://doi.org/10.1016/j.foodchem.2010.06.077

5. Guiné, R.P.F., Duarte, J., Ferreira, M., Correia, P., Leal, M., Rumbak, I., Baric, I. C., Komes, D., Satalic, Z., Saric, M. M., Tarcea, M., Fazakas, Z., Jovanoska, D., Vanevski, D., Vittadini, E., Pellegrini, N., Szucs, V., Harangozó, J., EL-Kenawy, A., EL-Shenawy, O., Yalcin, E., Kösemeci, C., Klava, D., Straumite, E. (2016). Attitudes towards dietary fibre on a multicultural basis: a fibre study framework. Current Nutrition \& Food Science, 12 (2), 132-141.

https://doi.org/0.2174/157340131202160412171430

6. Guiné, R., Duarte, J., Ferreira, M., Correia, P., Leal, M., Rumbak, I., Baric, I., Komes, D., Satalic, Z., Saric, M.M., Tarcea, M., Fazakas, Z., Jovanoska, D., Vanevski, D., Vittadini, E., Pellegrini, N., Szucs, V., Harangozó, J., EL- Kenawy, A., EL-Shenawy, O., Yalçin, E., Kösemeci, C., Klava, D., Straumite, E. (2017) Benefits of dietary fibre to human health: study from a multi-country platform. Nutrition \& Food Science, 47 (5), 688-699.

7. Huang, T., Xu, M., Lee, A., Cho, S., Qi, L. (2015). Consumption of whole grains and cereal fiber and total and cause-specific mortality: prospective analysis of 367,442 individuals. BMC Medicine, 13 (1), 59. https://doi.org/10.1186/s12916-015-0294-7

8. Kendall, C.W.C., Esfahani, A., Jenkins, D.J.A. (2010). The link between dietary fibre and human health. Food Hydrocolloids, 24, 42-48. https://doi.org/10.1016/j.foodhyd.2009.08.002

9. Ljubicic, M., Matek Saric, M., Rumbakd, I., Colic Baric, I., Komesd, D., Satalic, Z., Guiné, R. P.F. (2017). Knowledge about dietary fibre and its health benefits: A cross-sectional survey of 2536 residents from across Croatia. Medical Hypotheses, 105, 25-31. http://dx.doi.org/10.1016/j.mehy.2017.06.019

10. Macagnan, F.T., da Silva, L.P., Hecktheuer, L.H. (2016). Dietary fibre: The scientific search for an ideal definition and methodology of analysis, and its phy- 
siological importance as a carrier of bioactive compounds. Food Research International, 85, 144-154. https://doi.org/10.1016/j.foodres.2016.04.032

11. Martinho, C.A.C., Correia, A.C., Gonçalves, F.M., Abrantes, J.L., Carvalho, R., Guiné, R.P.F. (2013) Study about the knowledge and attitudes of the Portuguese population about food fibres. Current Nutrition \& Food Science, 9 (3), 180-188.

12. Sardinha, A.N., Canella, D.S., Martins, A.P.B., Claro, R.M., Levy, R.B. (2014). Dietary sources of fiber intake in Brazil. Appetite, 79, 134-138. http://dx.doi.org/10.1016/j.appet.2014.04.018

13. Slavin, J., Jacobs, D. (2010). Dietary Fiber: All Fibers Are Not Alike. In Nutrition and Health: Nutrition Guide for Physicians. Eds. T. Wilson et al. Humana Press, a part of Springer Science+Business Media, LLC 2010. http://dx.doi.org/10.1007/978-1-60327-431-9 2

14. STATISTICA (Data Analysis Software System) (2017). v.13.2., Stat-Soft, Inc., USA.

15. Szűcs, V., Guiné, R., Leal, M., Ferreira, M., Correia, P., Duarte, J. (2017). Dietary fibre: eating habits and knowledge in different regions of the globe. Millenium, 2 (2), 61-71.

16. Tarcea, M., Fazakas, Z., Ruta, F., Rus, V., Zugravu, C., Guiné, R. (2016). Romanian knowledge and attitudes regarding dietary fibers. Bulletin UASVM Food Science and Technology, 73, 123-128. https://doi.org/10.15835/buasvmcn-fst:12329

17. (US-FDA) United States Food and Drug Administration (2001). Food labeling: health claims; soluble fiber from whole oats and risk of coronary heart disease. Docket No. 95P-0197, 15343-15344.

18. Vuksanović, N.D., Popov Raljić, J.V., Portić, M.J., Dragičević, D.I. (2016). Hypersensitivity to certain food and food ingredients in the function of age and employment of customers on a cruise ship. Food and Feed Research, 43 (1), 25-33. http://dx.doi.org/10.5937/FFR1601025V

19. (WHO) (2013). Global action plan for the prevention and control of noncommunicable diseases 20132020. Geneva, Switzerland. http://apps.who.int/iris/bitstream/10665/94384/1/9789 241506236 eng.pdf?ua=1) accessed date 03.11 .2017 .

\section{ПРЕХРАМБЕНА ВЛАКНА И ХЛЕБ: СТАВОВИ, МИШЉЕЊА И ЗНАЊЕ ОМЛАДИНЕ}

Зита И. Шереш ${ }^{1}$, Драгана М. Шороња Симовић ${ }^{1}$, Маја Ј. Грујичић ${ }^{2}$, Ференц Е. Киш ${ }^{3}$, Маријана 3. Ђорђевић ${ }^{1}$, Оливера Д. Шимурина ${ }^{4}$, Жана В. Шарановић ${ }^{5}$, Никола Р. Маравић

'Универзитет у Новом Саду, Технолошки фракултет, Катедра за инжењерство угљенохидратне хране, 21000 Нови Сад, Булевар цара Лазара бр. 1, Србија

${ }^{2}$ Универзитет у Новом Саду, Медицински факултет, Катедра општеобразовних предмета, 21000 Нови Сад, Хајдук Вељкова бр. 3, Србија

${ }^{3}$ Универзитет у Новом Саду, Технолошки фракултет, Катедра за опште инжењерске дисциплине, 21000 Нови Сад, Булевар цара Лазара бр. 1, Србија

${ }^{4}$ Универзитет у Новом Саду, Научни институт за прехрамбене технологије у Новом Саду, 21000 Нови Сад, Булевар цара Лазара бр. 1, Србија

${ }^{5}$ Економски институт, 11000 Београд, Краља Милана бр. 16, Србија

Сажетак: Повезаност прехрамбених влакана са превенцијом масовних незаразних болести потврђена је великим бројем истраживања чији су резултати доступни у научној литератури. Упркос овој чињеници већина људи и даље не поседује довољно знања о прехрамбеним влакнима и њиховом садржају у прехрамбеним производима. Ово истраживање спроведено је у форми анкетног упитника како би се испитало знање омладине у Србији о прехрамбеним влакнима и биоактивним материјама. Истраживањем је обухваћено 173 испитаника (37\% мушкараца и $63 \%$ жена) насумично одабраних међу ђацима основних и средњих школа и студентима у Новом Саду. Анкетни упитник обухватио је питања о познавању термина прехрамбена влакна, садржају влакана у различитим врстама хлеба, повезности влакана са општим здрављем организма и намирницама које су извор биоактивних материја. Резултати добијени за свако од појединачних питања разликовали су се међу испитаним групама али је ниво знања, генерално гледано, био повезан са нивоом образовања. Највећи ниво знања о прехрамбеним влакнима и биоактивним материјама показали су студенти премда су и ђаци основних и средњих школа исказали задовољавајући ниво знања о испитиваној проблематици. На постављена питања о биоактивним компонентама веће знање показали су мушки испитаници, док су на питања о прехрамбеним влакнима веће знање показали женски испитаници. Спроведеним истраживањем утврђено је да је омладина у Србији добро информисана о значају прехрамбених влакана и биоактивних материја у побољшању и очувању здравља. Међутим, како би се побољшало здравље читаве заједнице неопходно је даље проширивање већ постојећег знања о овој проблематици.

Кључне речи: прехрамбена влакна, унос влакана, анкетни упитник, омладина, хлеб 